Japanese Research in Business History 2004 | 21

\title{
Wartime Mitsubishi Aircraft Engine Manufacturing and the Formation of Production Technology
}

\author{
Hiroko MAEDA \\ Kobe University
}

He AIRCRAFT manufacturing industry, one of the key industries
in Japan during the war years (1937-1945), and in particular the
mass production of aircraft engines, are extremely important areas to look at when considering the country's industrialization and production technology after the war. At the time that the Japanese government realized that large-scale production of aircraft was essential for prosecution of the war, the manufacturing capabilities of Japanese industries were not at a level that could meet that need. An aircraft engine was a machine product that at the time required the highest of high technology to produce: it involved many problems entailing the application of scientific principles, and it was made up of numerous parts, the machining operations of which were long and complicated and whose finishing had to be of a remarkably high level of precision. So it was a product that stood at the peak of an integrated industry. At a time when it was an absolute must to produce-in large quantities, in a short space of time, with priority given to quality when all production elements were under strain-a mass of metals that was a conglomeration of highly technical and diverse products of precision tooling, pro- 
duction sites in Japan's lagging manufacturing industries were forced to undergo change in all senses of the word.

In this paper I shall look at Japan's attempts at producing aircraft engines in large numbers during the war years and study what, in the process, people thought about production technology, and how it was accumulated on the production sites themselves. I place, especially, importance on the role and contribution of Junji Fukao, the key person in the matter with regard to the formation of production technology on the production sites. ${ }^{1}$ Considerable research has already been done on aircraft production during the war. ${ }^{2}$ What sets this paper apart from previous research is the fact that: (a) I have chosen to look at the aeroengine division of Mitsubishi Heavy Industries, Ltd. (hereafter, Mitsubishi), which has not been studied systematically in the past despite its key role in munitions production during the war; (b) focusing on the role of production engineers (Fukao was one of the most outstanding figures among them), I have relied heavily on personal interviews with and materials from people who had personal knowledge of the actual production sites; and (c) I have included within my field of vision a comparison with the American aircraft engine manufacturing industry.

1. Junji Fukao was born in 1889 and died in 1977. He graduated from the Machinery Department of Tokyo Higher Technical School, entered Mitsubishi Gōshi Kaisha's Kobe Shipyard \& Engine Works, and worked there and at Nagasaki Shipyard \& Engine Works, whence he was transferred to Mitsubishi Aircraft in 1933. He served as director of Nagoya Engine Works, and in 1941 he became a director on the board of Mitsubishi Heavy Industries, Ltd., in his capacity of director of the Aero-engine Division. Throughout the war years he consistently worked for integration of that expanding division and displayed strong leadership. He was, in the true sense of the word, the key person in regard to development and production in that division. This paper is greatly indebted to written documents and materials left behind by Mr. Fukao.

2. Some examples are Kiyoshi Yamamoto, Nihon ni okeru shokuba no gijutsu/rōdō shi 1854-1990 [A history of workplace technology and labor in Japan, 1854-1990] (Tokyo: University of Tokyo Press, 1994); Satoshi Sasaki, "Dainiji sekai taisenki no Nihon ni okeru seisan shisutemu no gōrika no kokoromi: Nakajima Hikōki Musashino Seisakusho no jirei o chūshin ni" [Attempts at rationalization of production systems in Japan during World War II, with special reference to the case of Nakajima Aircraft Company's Musashino Works], Keieishigaku [Japan Business History Review] 27 no. 3 (1992); and Kazuo Wada and Takao Shiba, "Nihonteki seisan shisutemu no keisei" [The formation of the Japanese-style production system], in "Nihonteki" keiei no renzoku to danzetsu [Continuity and discontinuity in "Japanese-style" management], ed. Hiroaki Yamazaki and Takeo Kikkawa (Tokyo: Iwanami Shoten, 1995). 
The Aircraft Industry Control Law promulgated in 1938 might have attracted the interest of a large number of related businesses, but the production of engines, with its high barriers in terms of both technology and costs, was a classical case of an oligopoly. Effectively, ninety percent of the engines that were suitable for actual battle conditions as regards such properties as horsepower, performance, reliability, and durability, were produced by just two companies: Mitsubishi and Nakajima Aircraft Company (hereafter, Nakajima). Because the former not only was producing the lion's share of engines produced but also had the capability to produce high-tech special parts and special machine tools, its technological importance was exceptional. It would seem reasonable to assume that, in the desperate conditions in which in the end all companies were under strong pressure to produce as many planes as they possibly could, the highest production technology in Japan at the time would be found at the aero-engine division of Mitsubishi.

In Japan's machine industry as a whole, it was in the midst of the buildup of wartime productivity that questions began to be asked about production technology itself, and it was the airplane that stood at the pinnacle of the machine industry. Since the airplane represented the product of an emerging industry, the amount of preparation time available for studying production technology was limited. This notwithstanding, with the establishment of the Munitions Ministry in November 1943 the principle that airplanes were the top priority was clearly set down, and all the country's efforts were channeled into increasing aircraft production. In a sense, the production technology possibilities and limitations of the late-starting industrialized nation of Japan were tested. This paper presents one of the best examples of how they were tested.

AIRCRAFT ENGINE PLANTS UP TO THE MID-1930S

The beginnings of aircraft engine production by Mitsubishi go back to the development of internal combustion engines that was initiated within the Kobe Shipyard \& Engine Works, which was a link in the diversified operations strategy of the company's heavy and chemical industries division. The aircraft engine section was moved out of the Kobe plant in 1920 with the building of a plant in Ōe, adjoining the 
Port of Nagoya area. This plant carried out the development of both airframes and engines, principally through the introduction of overseas technology; in 1928 it was made an independent company under the name Mitsubishi Aircraft Co., Ltd. (hereafter, Mitsubishi Aircraft). Then in 1934, in the wake of the establishment of Mitsubishi Heavy Industries, Ltd. as a result of the merger of Mitsubishi Aircraft and Mitsubishi Shipbuilding Co., Ltd., the name of this plant was changed to Nagoya Aircraft Works.

Now, even though Japan's aircraft industry was the product of military demand, its production operations were entrusted practically to the private sector. Mitsubishi Aircraft's customers were almost entirely restricted to the military-more specifically, to the Army and the Navy. Once a certain level of results was achieved in manufacturing through the introduction of overseas technology, the two forces adopted a policy of mutual technological independence, and they competed with each other in experimental manufacturing-while at the same time both forces shared the conviction that domestic production of airframes and engines was an absolute necessity. The Army and the Navy each issued its own specifications, and the company had one set of people in charge of the Army's work and another set of people in charge of the Navy's work; development was attempted separately, and not even an exchange of technology within the company was carried out. Under such conditions, from the second half of the 1920s and through the first half of the 1930s Mitsubishi Aircraft bumped up against one technological barrier after another in its production of airframes and engines, and it was unable to produce high-grade aircraft one hundred percent of its own making. In the second half of the 1930s, however, it achieved technological self-reliance in both engine and body production and succeeded in developing its own products; from that point on, it would rapidly expand its production (sparked in great part by increased military demand). With this necessarily rather simplified overview to serve as a general background, I now propose in the remainder of this paper to narrow our focus and limit our attention to the company's engine production.

Up to the middle of the 1930 s the main emphasis at the engine plant was upon experimental manufacturing. The priority was the absorption of overseas technology and the development of domestic products; 
no products were produced in large quantities. Individual pieces were for all practical purposes handmade, one at a time, and no thought was given to production technology as such. Lathes and the like were driven by a belted line shaft, and they were fixed to the floor along with their electric motors. Various kinds of tubes and pipes trailed along the floor, not only creating hazards underfoot but also making it difficult to move machines to other locations. Machine tools from the best Western manufacturers had been brought in, so the designing of jigs and tools took place, but there was almost nothing along the lines of a precision processing machine. No fixed procedures for making any individual part were set down, nor did any job standards exist. Still, every work site was in the charge of a $k \bar{s} s h$, an expert with many years of experience esteemed for his exceptional technical skills; his job was to devise the methods to be used in making the various parts and to teach the other workers how to follow those methods.

It was in the area of manufacturing forgings that the company's workers were especially technically backward. A large amount of effort was spent on grinding forged pieces because of the thick surfaces to be smoothed. Whenever the technicians in the forging section saw the forged parts imported from America, which required almost no grinding at all, they became all too conscious of the gap between the two countries in machining technology. The most important work in the plant was finishing, and the workman who ranked highest in the factory was the $k \overline{o s h} i$ in charge of the finishing shop. Many of the parts for an engine required finishing touches by expert workmen before they were ready to be fitted into the engine. To put the matter another way, when you have state-of-the-art technology that is still not standardized, you frequently have to rely on high-level on-the-job skills. This was even more necessary in a situation in which there were so many types of manufacturing machines, in which there was such an abundance of multipurpose machine tools, and in which the tools and the methods of making the parts had to be changed in so many different ways.

FIRST STEPS IN PLANT REFORM

In 1932 Mitsubishi Aircraft in Nagoya was expanded through a doubling of its capital. The event marked the beginning of rapid changes in the 
plant. The rationalizing improvements in daily operations that naturally follow from experience accumulated in conditions in which production quantities increase or in which future order increases could be foreseen were important, but even more important was the transfer of production technology from the shipbuilding division of Mitsubishi. This transfer came about principally in the middle of 1933, when the company posted Junji Fukao and his immediate subordinate, Sen'ichi Satō, from Nagasaki Shipyard \& Engine Works to Mitsubishi Aircraft's Engine Department. These two men were shrewd "production engineers" who had the experience of having weathered the engine construction plant rationalizations the company was forced to carry out in the shipbuilding recessions that followed World War I and the Great Depression. These two were at the heart of the major reformation that was to take place at the Mitsubishi Aircraft engine plant.

First of all, over a great deal of resistance from the finishing workers, decisive action was taken to do away with files and scrapers; even the honing of bits by individual workmen was banned and was to be done in the tool room of the plant instead. Standardization of parts was introduced. In the manufacture of aircraft engines, in which a large number of experimental elements are always involved, sometimes even screws and bolts were of a special make. As a result, things that were supposed to have been made according to blueprint specifications would not fit properly when parts were being assembled, or they broke or were damaged during test runs. Such situations were happening with frequent occurrence. So finally attempts were made to raise the level of compatibility of parts and to do away with random variations in quality. The company adopted tolerances given in microns, and inspection operations were made stricter.

In addition, time study was introduced, the first time such a thing had been attempted at Mitsubishi Aircraft. The method was learned at the fan plant of the Mitsubishi Electric Manufacturing Co., Ltd., which already had experience of it, and then it was applied at Mitsubishi Aircraft to break down the manufacturing process into small parts and do an analytic study of each of the parts, then aim at the realization of flow manufacturing by appropriate placement of equipment and personnel. At the same time, the company created a system that incorporated the Halsey Premium Plan, according to which time standards were estab- 
lished for each operation, and extra wages were paid proportionately for the amount of time by which workers finished their work faster than the standard time. A motion study that would result in more efficient operations and the establishment of operation standards went ahead simultaneously. Actual time standards were decided upon after much discussion-not always coming to unanimous conclusions-by the expert workers in all areas. Enormous amounts of data were gathered through these studies.

The earlier reliance on multipurpose machines would be gradually replaced by greater use of specialized machines, or single-purpose machines, and at the same time the types and numbers of tools would be put into a manageable order, but because decisions about reducing the number of engine models had to be made first, sorting out the machine tool problem required time. Furthermore, it took over a year to get into full-scale operation some of the expensive top-grade machine tools that were imported from the United States on the occasion of the plant's expansion. Showing how to make best use of these machines-showing their performance effectively by using them to produce special tools and jigs and the like-provided the machine technicians with the opportunity to show off their own competence and skills. It was at this time that a new method of boring holes was introduced; instead of revolving the piece being processed, in the new method the cutting pieces were revolved, making use of high-speed tools that were fitted with a number of cutting blades. A simple but original form of the work sheet that had been started around 1930-an attempt to indicate to workers the job they were to do, not just verbally but also in an easily understandable graphic form-began to work smoothly. Several years later many of these reforms would develop into an independent business operation given the label "production design," which would include things like the designing of machine tools and jigs. This whole series of changes, let it be noted, was the germ of what is known today as "production technology."

The rapid changes that followed Fukao's posting stemmed from an attempt to industrialize anew a manufactured product (an aircraft engine) that lay beyond the community's capacity to industrialize, if I may put it that way. It represented a switch of emphasis from considering the finishing shop the heart of operations to considering the 
machine shop the heart of operations, and then a further shift to considering the materials the heart of operations. In other words, the center of gravity shifted away from the finished product to earlier stages of the production process. There would be no prospect of large-scale production unless earlier stages were reformed. At the same time, there had to be "a shift from technical skill to technical know-how." There was no denying that on-the-spot technical skills were outstanding, but as long as the plant had to rely on the abilities of certain expert workers for its products to be completed, the plant's limitations were obvious. The ultimate goal had to be the solid entrenchment of the manufacturing methods and processes so that the same results could be expected no matter who was working. And so the real power over craftsmanship in the plant was shifted from the people with on-the-spot technical skills to the corporation itself-in the concrete, to people with technical know-how. This having been said, there still remained parts of the manufacturing process in which expertise could not be done away with, and so on-thespot technical skills continued to be prized.

Now, in the mid-1930s, while plant reform was unfolding, two important changes in the company's situation would take place. The first, external in nature, was the growing trend toward military preparedness, which gave promise of increasing orders for aircraft and the imminent enactment of the Aircraft Industry Control Law. The second, internal, was the company's success, after several years of getting nowhere, in developing its own engine-in other words, its achievement of technological independence. Though there is no room in this short paper to go into details, let me point out that, in regard to the development of the company's own engine, it was Fukao, then head of the Engine Department, who acted the part of a "super-heavyweight product manager." ${ }^{3}$ The reason I presume to tack on the prefix "super" is that he managed to reorganize the setup whereby separate groups were working with the numerous different specifications coming from the Army and from the Navy, forming instead one large project team made up of experts from different areas; he then put a stop to any intervention or interference

3. For an explanation of the term "heavyweight product manager," see Kim B. Clark and Takahiro Fujimoto, Product Development Performance: Strategy, Organization and Management in the World Auto Industry (Boston: Harvard Business School Press, 1991), pp. 254-65. 
from the customers and advisers (namely, personnel from the Army and the Navy), so that the company could develop its own engine under its own leadership and initiative. Fukao's high-handed, arbitrary decision making not only greatly offended the feelings of people in the military, it also created problems within the company itself, and relations in both areas grew ugly. Nevertheless, Fukao stuck to his guns, and the successful development of this engine-the air-cooled 14-cylinder Venus 40 model with 1000 horsepower that acted as the prototype-resulted in a subtle enhancement of the influence of anything Fukao had to say, both within the company and with the military. It is no exaggeration to say that the grand design of the subsequent development and production of Mitsubishi aircraft engines basically (albeit within the restriction of munitions production) followed the plans of Fukao. This grand design represented an interesting contrast with the development and production system at Mitsubishi's main rival, Nakajima. ${ }^{4}$

\section{NAGOYA ENGINE WORKS}

In anticipation of increasing orders, in July 1938 Mitsubishi made the engine division of its Nagoya Aircraft Works plant a separate entity under the name Nagoya Engine Works (hereafter, NEW). A large plant was built on land acquired from the Kanegafuchi Spinning Company, in Daikō-chō in the northeastern part of Nagoya City, near the Yada River (and including the present-day site of Nagoya Dome). Junji Fukao was appointed its first director.

The new plant was modeled on the East Hartford Plant of the Pratt \& Whitney Aircraft Co. (hereafter, P \& W), one of the two major manufacturers of aircraft engines in the United States (along with Wright

4. In Akio Ōkōchi’s article "Nakajima Hikōki to Rōrusu Roisu—senkan/senchūki no gijutsu kaihatsu to kigyōka" [Nakajima Aircraft and Rolls Royce: Technological development and industrialization between the wars and during World War II], in Kigyōsha katsudō to kigyō shisutemu [The activities of business people and enterprise systems], ed. Akio Ōkōchi and Haruhito Takeda (Tokyo: University of Tokyo Press, 1993), there is a description of the situation at Nakajima: the absence of a prototype (an engine that can be produced in large quantities for a long time with the addition of improvements) and the lack of enough "entrepreneurs," excessive interference by the military, divergences between design and production-all of them features that mark a very different situation from the one we are looking at in Mitsubishi. 
Aeronautical Corporation). Because the company was determined not to be outdone by its rival, Nakajima, which was a step ahead of it and was already building a new plant called Musashino Works, the new NEW was to incorporate features, which I summarize below, that were epoch-making in that they revolutionized the concept of a factory that was common in Japan at the time.

First of all, it was an enormous, sprawling plant made up of mainly one-story buildings. Because of the priority given to functionality and a bright working environment, the walls and ceiling were painted white, and aisles were provided for trucks to pass through the inside of the building. The partitions between working sites were set low to allow for a good view covering a wide area; this was especially effective in keeping indirect-labor workers, who had no time standards set down for their work, industrious. The plant was surrounded completely by lawn; the entire floor in each building was concreting. Machine tools were not set upon any wooden platforms, nor were they bolted to the concrete floor. Instead of being set on the ground, things like power lines, steam pipes, air ducts, and heating equipment were attached to roof trusses. In effect, this arrangement meant it was easy to move machine tools around in response to changing needs, and access to electric power was easily obtained. In addition, partial second stories were built over the inspection sites and the machine shops to house medium-voltage transformer substations, toilets, and washrooms. (At the time, the common practice was for toilets to be located outside the building, but installing toilet facilities within greatly reduced lost working time.) A few dozen cleaners were hired permanently, and they not only maintained cleanliness at all times but also helped to keep things tidy and in order and to prevent fires. Because at the Ōe Plant complaints about noise came in even from people living far away from the site, NEW built its cells for testing the engines with soundproof concrete walls. The office wing was a ferroconcrete construction of four floors, with a splendid, bright room for the designers on the top floor; it was to inspire them to aim at designing the best aircraft engine in the world.

While the company made good use of the data it had gathered in its earlier time and motion study when it chose the flow line that is shown in Figure 1, even there the basic ideas followed the P \& W system. The production line, in which "raw materials were inserted at both sides of 
the factory, machined as they moved to the central area (where they were inspected), and then carried by vehicle to the assembly area. The assembled engines were then tested in testing cells out behind the factory, after which they were taken back to the assembly area, where they were disassembled and cleaned, reassembled, packed, and shipped,"5 is practically the same as the one used at $\mathrm{P} \& \mathrm{~W}$ (Fig. 2). The biggest difference between the machine shops here at NEW and those in the old Ōe Plant was in the arrangement of machines according to manufacturing process instead of according to type of machine. Whereas at Ōe they had machines that did the same kind of work grouped in one place and they separated the machining sites from the finishing sites, at NEW they had different types of machine tools-for example a lathe, a drilling machine, and a milling machine-lined up in the order of processing, and within that flow of machining they would process a piece, inspect it during the process and at the end of the process, and then temporarily store it in the finished parts storeroom. ${ }^{6}$ Though this method was still imperfect as a flow operation method goes because it lacked the ability to compel workers, time-wise, to keep things moving along, it is noteworthy that such a system of production had been adopted in Japan as early as 1938. Also, in connection with P \& W, it is necessary to note the following three important points.

First, P \& W's production method was not the typical American mass production method exemplified by that of Ford Motor Company. Even in America at this time, the amount of aircraft being produced was still small, there were frequent design changes being made to military planes, and technological improvements were of rapid occurrence. Losses from unnecessary processing of parts for a single engine were so extremely great that parts were not made in big lots, and it was an

5. Ryōkōkai, ed., Ōji bōbō: Mitsubishi Jūkō Nagoya gojūnen no kaiko [Bygone times seen dimly in the distance: Reminiscences of fifty years of Mitsubishi Heavy Industries in Nagoya], vol. 1 (Nagoya: Ryōkōkai, 1970), p. 545.

6. The inspection consisted of a two-tiered system in which first a worker made a "process inspection" with a gauge during the processing of a part, and when the process was finished an inspector would carry out a "part inspection" of the piece a second time. The first inspection was carried out on all parts, while there is a strong likelihood that the second was carried out on all parts to begin with, but as the number of pieces produced grew in number, this changed to sampling inspections. These inspections should not be taken to be as strict as those implemented when Statistical Quality Control was introduced after the war. 
Figure 1. A Conjectural Chart of the Plant Layout and Production Lines in the Production Department, Nagoya Engine Works (1938-1939)

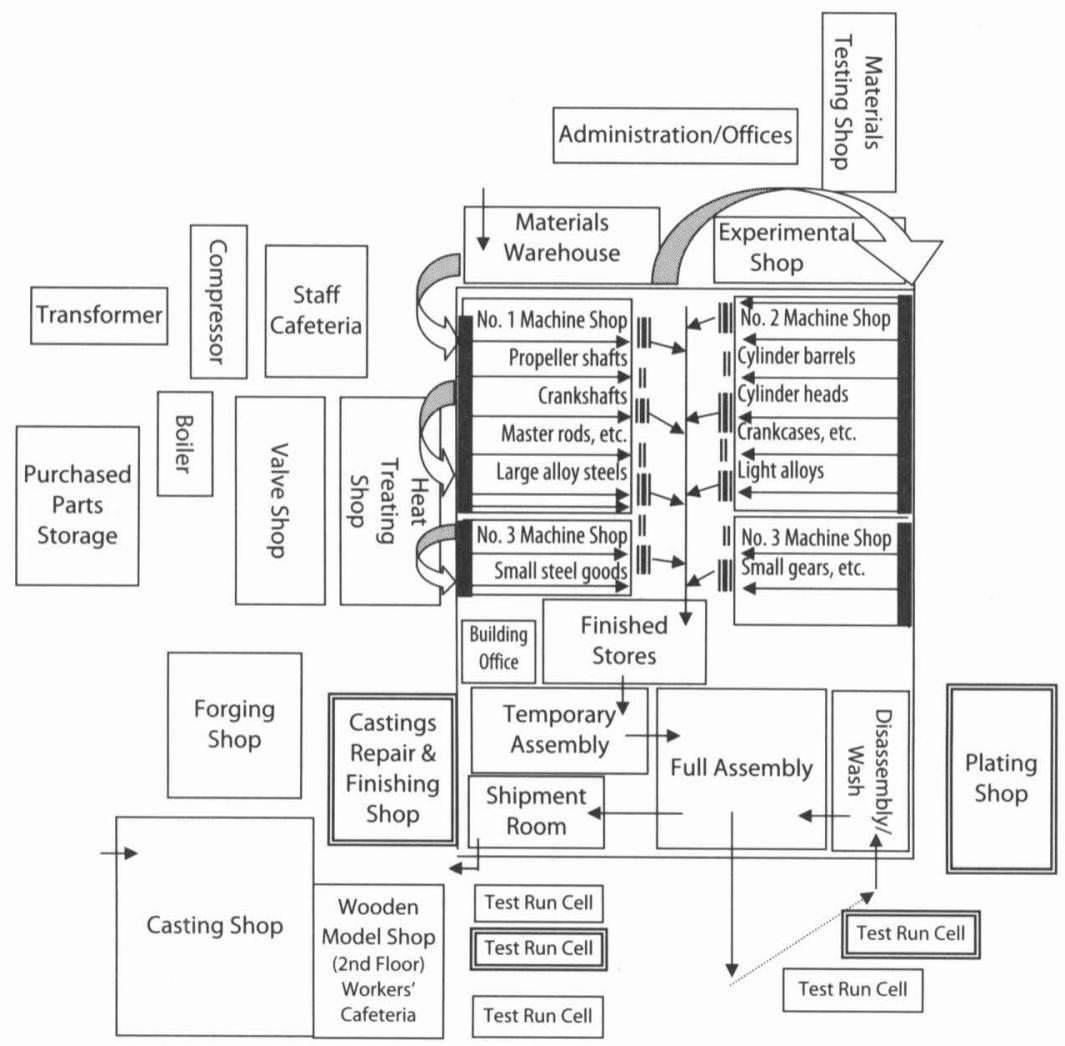

Sources: “Aircraft Division: Corporation Report," The Final Reports of the United States Strategic Bombing Survey, vol. 1 (U.S. Government Printing Office, 1945-47), Appendix A; Daikō zuisō Editor, comp., Daikō zuisō (Daikō zuisō Kankō Hokkinin [Publication Sponsor], 1997), frontispiece; and information obtained from personal interviews from employees who worked there at the time. 
Figure 2. Layout and Production Lines at P \&W's East Hartford Plant (1937-1939)

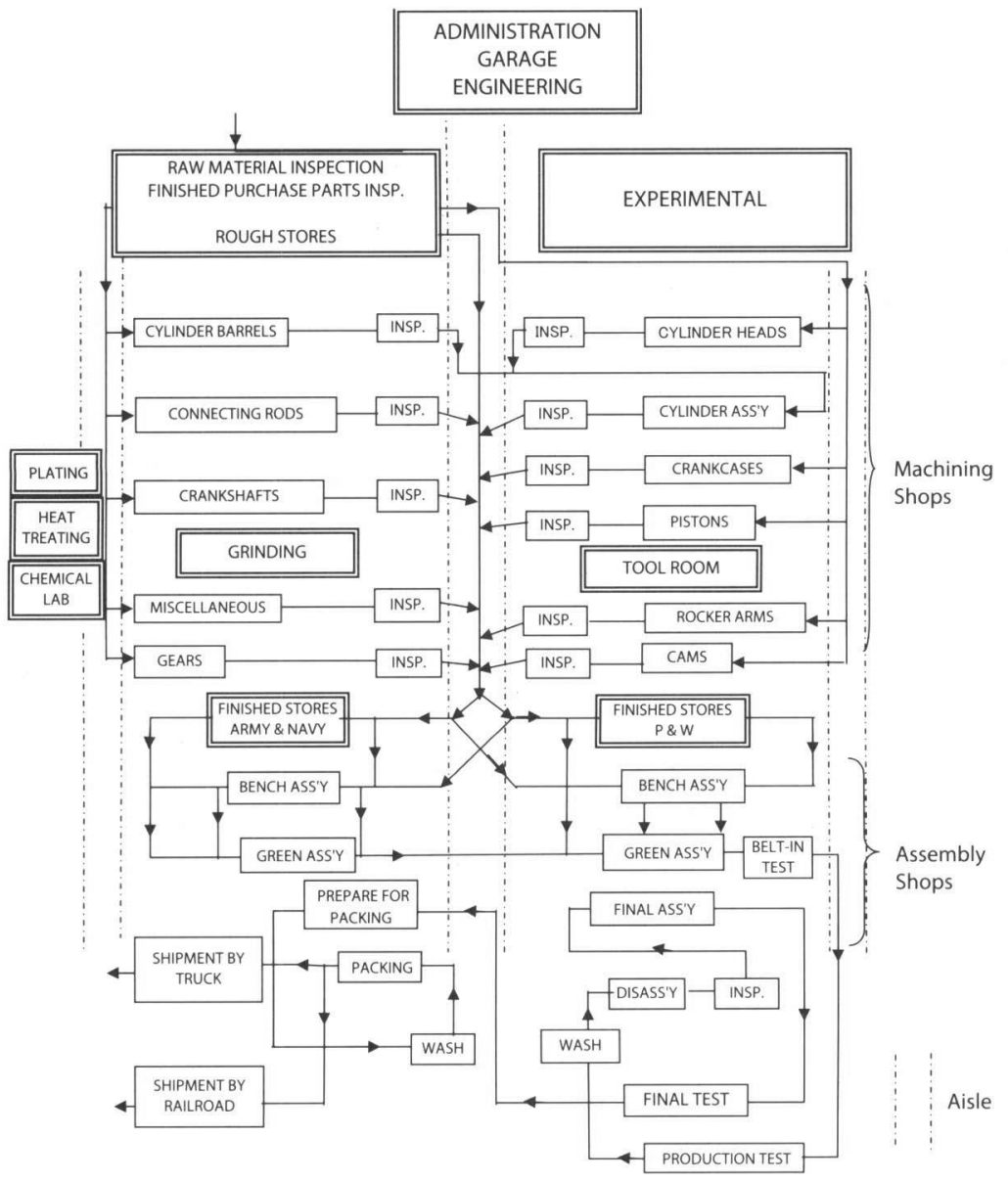

Sources: The above chart is a summary outline stressing the flow of products and is produced from materials found in J. Carlton Ward, Jr., "Plant Layout and Production Methods for Modern Aircraft Engines," SAE Journal 40, no. 5 (May 1937), p. 167; "P \& W Engine Production," Aero Digest (January 1939), p. 57 (no author given). 
ironclad rule that one did not stockpile parts. It is believed that P \& W adopted a production line that was as simple and flexible as possible, to be prepared for design changes made by their customers, and for the possibility of large-quantity orders resulting from changes in the political and economic environment. If there was anything that Mitsubishi officials learned from P \& W when it designed NEW, it was that the key to forming an aircraft engine production line was making it as simple and flexible as possible. ${ }^{7}$

Second, there was, nevertheless, a huge difference between $\mathrm{P} \& \mathrm{~W}$ and NEW especially in regard to the system for manufacturing parts. $\mathrm{P} \& \mathrm{~W}$ internally manufactured vital parts that were frequently subject to design changes, but the majority of parts were supplied through the open market or else from subcontracted parts makers. And materials for castings and forgings were purchased entirely from outside sources. The plant organization at NEW, however, according to which almost all parts-including both the actual parts and the machine tools to make them-had to be made internally, could not follow the P \& W pattern, and instead necessitated having a group of factories ringing the plant to provide the various relevant industries and products. Figures 1 and 2 show this difference clearly. There was also a huge real difference when it came to the performance of machine tools, even though the difference was not so conspicuous when only small production quantities were involved.

Third, the production method inaugurated by NEW at this point in time did not mean that a huge jump in production was possible right from the start, nor did it mean that later there was a smooth transition to a method of mass production as we understand the term today. A huge gap was to widen between Japanese and American aircraft engine

7. Emphasis was put on moving machine tools from place to place, rather than using conveyors. For more on the P \& W production method at the time, see H. E. Black, Jr., "Precision," Automotive Industries 77 (July 1937), pp. 11-16; J. Carlton Ward, Jr., "Plant Layout and Production Methods for Modern Aircraft Engines," SAE Journal 40 no. 5 (May 1937), pp. 178-89; and "P \& W Engine Production," Aero Digest (January 1939), pp. 57-59 (author not identified). Let it be noted, however, that at the end of the 1930s production lines like those at P \&W "did not flow as smoothly as they looked on paper" (quoted in Satton, Pāku ryōshi kōkū hatsudōki tairyō seisan ni kansuru kōshū roku [A record of the short courses given by Messrs Sutton and Park on the mass production of aircraft engines], vol. 3, published by Mitsubishi Heavy Industries, Ltd., Nagoya Engine Works, 1939, p. 76. 
production technology by the end of the war. As we shall see later, the production system at NEW was gradually extended and improved, and it manifested a high level of production capability in comparison with the production technology level reached anywhere else in Japan. But because of the shortages in materials, machine tools, and skilled workers, and because of the chaos caused by imbalances in orders and forced expansion, and similar factors, the expected improvement in results did not eventuate, so that once the Allied air raids began at the end of 1944, the company's operations plunged headlong into a complete collapse.

Whatever the results, however, the reform of production technology trialed at this new plant was an epoch-making event in the history of Japan's machine manufacturing industry. Around the time that NEW was hived off as an independent entity, the war between Japan and China was showing signs of bogging down and there was a sudden jump in orders for aircraft that exceeded all expectations. It was a time when the aircraft manufacturing industry would make a genuine search for means to achieve production on a large scale.

\section{STRATEGIES FOR LARGE-SCALE PRODUCTION \\ BEGINNING WITH STRUCTURAL DEVELOPMENT}

When it came to increases in all the different production elements, which is the very first step that can be taken towards large-scale production, the aircraft manufacturing industry would receive preferential treatment under the wartime controlled economy, but this preferential treatment would also be accompanied by pressures resulting from wartime conditions. I would add that parts and processing that could be purchased from outside the company were considerably limited, owing particularly to problems connected with quality. In connection with worker morale and worker skills, the problem of work duties and education was also important. There is insufficient space for me to go into these questions in the present study, so I propose to limit my focus to only the more central elements of production technology. The most important points of the reform at NEW were: the machinery aspect (the use of specialized machines); the process aspect (analysis, supervision, and the cutting back on man-hours); and the structural aspect (the sep- 
aration into specialized factories). These are the aspects that I propose to study in connection with the actual organizational development.

\section{The Production Design Section and the Production Engineering Department}

From the point of view of production technology, the features of NEW's new structural setup were the establishment of a Technical Department that coordinated research, design, and experimental manufacture, and a Production Design Section that was newly established within a Production Department that coordinated all the production sites. The function of the Production Design Section was that of integrating the designing and making of specialized machines, jigs, and tools as well as all the different attempts at an organic union between design operations and worksite operations. NEW would have been among the first companies in Japan's manufacturing industries to establish an office that was of such a production-technology nature. Faced with calls for a rapid increase in production, Fukao formulated a basic response: he would have the few available skilled workers make specialized machines that could easily be operated even by unskilled workers, and have the large number of unskilled workers use those machines to produce aircraft engines on a large scale.

With a view to strengthening this office's ability to oversee the preparations of production equipment, Fukao appointed to this office outstanding engineers who had graduated from university engineering departments, master workmen who had worked their ways up in the workplace, and competent skilled workers, with a view to improving the machinery aspect through an integration of technical know-how and technical skill. Production technology was no longer a matter of leaving things up to the random devices and efforts of each individual worker on the site; rather, it now had become something that had to be considered functionally within the perspective of plant management as a whole.

In December 1940 the Production Design Section, the tool shop, and the heat treating shop were combined, then integrated along with the people who were in charge of motors, metal plating, and time study, into a separate department given the name Production Engineering Department. This meant that "production technology affairs" were given recognition as being one of the main pillars supporting the organizational 
structure, and from this point on their importance rose rapidly. A new plant was built and equipped with 800 machine tools; it produced jigs and tools and specialized machine tools at a rate that astonished other specialist manufacturers of machine tools. Process analysis and efforts to reduce man-hours by reviewing processing methods and materials were also carried out in the new plant. In addition, as a step toward greater work control, the Department drew up an enormous number of work sheets that integrated the results of time study with the presentation of work instructions in easily understood graphic form mentioned earlier. Such work sheets were meant to enable anyone to carry out a job with willingness and efficiency and without mistakes, but in actual practice what happened was that the work sheets were kept in the possession of the people in charge of the work site and workers carried out their tasks in accordance with contractual work slips.

Another important function of the Production Engineering Department was its "production technology study meetings." At these meetings various engine parts would be set out on a table, and people involved in their design and manufacture would gather around the table and provide information about each individual part, covering such things as the ideas that went into its design and manufacture, what was done to compensate for degradation in the quality of the material, and how reduction in man-hours was achieved in its manufacture. These meetings were transdepartmental exchanges of information in which Fukao himself took the initiative. This practice, what might be termed value analysis through brainstorming, was carried over into the postwar period.

\section{Process Control Sections}

From the point of view of production technology, the part of the new structural setup that was equally as important as the Production Design Section and the Production Engineering Department was the creation of a Process Control Section-an office devoted specifically to process control-in each machine shop within the Production Department. The flow of process control operations in a machine shop can be summarized as shown below.

When a decision about the type of machine to produce came down, first a production plan was decided after a discussion with the relevant 
offices-process control, materials provision, purchasing, experimental design, manufacturing design, and inspection.

- Decisions were then made regarding the division of responsibilities in regard to internal processing of materials, putting out processed materials, and purchasing of finished parts from outside sources. Outside orders were placed and materials were sought. Delivered goods and materials were checked and confirmed. Material quantities were entered onto the progress board inside the plant. The materials were distributed within the plant (i.e., the required amounts were conveyed to the starting point of the processing procedure).

- The required numbers of smaller parts that were to be fitted into the larger pieces in the course of processing were distributed to those places where required, when required.

- When processing was finished, an inspection took place; items that were classified as finished goods, goods for reprocessing, and scrap goods were distributed, respectively, to the finished parts storage shed, the starting point of the processing procedure, and the scrap pile.

- The amount of finished goods was entered onto the progress board (where a diagram compared the amounts of finished goods with the anticipated amounts for thirty days).

- The required numbers of pieces were collected from the finished parts storage shed and sent in sets to the assembly shops, at the time designated by an assembly timetable issued by the assembly site.

The above was a form of procedure that required large numbers of slips of paper to be shuffled around and the work crews to be doing a lot of running around. The aim of this form of procedure was to have parts and attachments ready just when they were needed for the next step in the process. In this, we can see a forerunner of the Japanese-style production system that became prevalent after the war.

The key to aircraft engine production lies in the large-scale manufacture of parts that have compatibility as a result of precision machining. Now, while the advanced country of America was making improvements in this stage, its interest was shifting towards conversion of the assembly process so it would become flow operational. In Japan, on the 
other hand, the assembly process depended mainly on human-wave tactics, and a drastic transformation of the procedure would, for the time being, be put off till later. Here, a more important first priority was achieving a full and balanced timely provision of the parts and attachments to be assembled. To do this, it was deemed necessary to begin making changes with structural organization.

\section{Separate Casting/Forging and Valve-Making Facilities}

The first move toward structural reform by way of making specialized shops independent entities occurred when the casting and forging sections became an independent factory. For one thing, the military authorities gradually adopted a policy of allowing more and more of the materials for casting and forging to go to the businesses that were exclusively dealing with those materials. Fukao, however, was a keen advocate of making the materials for casting and forging, especially those for casting, within the company, for the sake both of ensuring quality and of keeping costs down.

The major key to increasing production of aircraft engines was the production technology involved in the castings that formed the bodies of the engines, and naturally this was an important task connected with the quality of raw materials. And yet up to this point in time the low level of technology in Japan's machine manufacturing industries as a whole was such that, not only was no pressure being applied to raise the quality of the castings as the basic molded materials-but also the matter was not even seen as a bottleneck preventing the further development of the machine manufacturing industries. ${ }^{8}$ Add to this the fact that castings were plagued by an image of being something heavy, crude, even technically primitive, and both engineers with high levels of specialized technical ability, as well as the work sites themselves, were rarely paid any attention to within the company organization. Fukao, however, had always been keenly aware of the importance of casting technology, and after he took up his post at Mitsubishi Aircraft, he set up a new Casting \& Forging Section, which later (after the establishment of NEW) became an independent factory within the Production Department. Then in April 1940 he made it the Casting \& Forging Department, incor-

8. Toshio Yamazaki, Gijutsu shi [The history of technology] (Tokyo: Tōyō Keizai Shinpōsha, 1961), pp. 116-18. 
porating within it casting, forging, and the bearings shop. Finally, in July the same year, he made it a completely separate factory, adding to it the shop that was specializing in large-scale production of air valves and exhaust valves, and it was given the name Nagoya Metallurgical Works.

Forging technology lagged behind casting, but with the installation of expensive imported machines like drop hammers and hydraulic presses, the factory began stamp forging. This led to phenomenal progress and the production of precision forged parts that could not be matched anywhere else in Japan. Between what they produced and what was produced in the United States, however, there still lay a huge gap.

Making the casting and forging sections an independent entity led to greater production efficiency. The war situation, however, expanded far beyond expectations, and this meant that far more orders came in than anyone had predicted. The result was further expansion by moving the valve and bearing shops to a separate factory: Kyoto Engineering Works. Since the production of exhaust valves was practically a Mitsubishi monopoly, the company felt it had a heavy responsibility to produce these in large quantities. Another reason for the move to Kyoto was a desire to avoid the risk entailed in having too many facilities concentrated in Nagoya.

\section{$R$ \& $D$ and Production Technology}

Along with the development of technology aimed at increasing production, the development of technology aimed at producing better products was also keenly pursued. In a reflection of the situation in those wartime years, young engineers of outstanding ability flocked to the aircraft manufacturing industry, which was continuing to experience unprecedented growth. At the same time, NEW managed to have several outstanding personnel transferred to itself from other manufacturing plants within the Mitsubishi zaibatsu group. Fukao also instituted a unique reward system to provide generous encouragement to R \& D efforts by staff.

In November 1943, when the Munitions Ministry was established, NEW's Technical Department, Materials Testing Shop, Experimental Shop, and Production Engineering Department were integrated and spun off from NEW as an independent entity known as the Nagoya Engine Research Institute. With a design office, materials and physics laboratories, test run facilities, and an experimental shop, it constituted 
a large-scale $\mathrm{R} \& \mathrm{D}$ division in which were brought together the cream of NEW's brains and technical expertise. Here were studied, and experimental manufacturing carried out on, large engines like the 18-cylinder Venus model and the 18-cylinder and 22-cylinder Mars models, fuel injection pumps, water injection, exhaust-gas turbine superchargers, liquid-propellant rockets, and turbojets. These efforts at technological development were an indication of the limits faced by a country where development was lagging behind and whose avenues for importing overseas technology were blocked by wartime isolation.

Now, at the time that the Nagoya Engine Research Institute was established, Fukao still was planning to go a step further and set up the Production Engineering Department as a separate facility, in order to have the production technology area working on its own. This plan never came to fruition, however, because the war situation would bog down and then collapse altogether, but it is significant that, at that point in time, the fact that production technology had that much importance in its own right was already clearly understood by people like Fukao. In other words, people realized that solutions were not to be found in a general "increased efficiency," that the importance of the technological development needed for producing a certain product in large numbers had grown in an extremely short period of time, and that an extension and improvement of that area was the key to the production capability of the enterprise.

Some of the engines and engine parts were successfully developed and marketed; as a result of production of fuel injection pumps and exhaust-gas turbine superchargers, the company was able to purchase the Iwatsuka Mill of Fuji Spinning Co., Ltd., which it converted into a specialized manufacturing works. This occurred in January 1944. Conversion of spinning mills and automobile manufacturing plants into aircraft-manufacturing-related factories had been considered and looked into in concrete detail from the very outbreak of the Pacific War, and in fact in December 1942 NEW had purchased the Ôzone Mill of Tōyō Spinning Co., Ltd., which was located not far from NEW, through the mediation of the military, and it had converted the mill into a specialized plant by training all the young female mill workers in the making of bolts, nuts, and similar small parts.

Mitsubishi had built five plants to produce engines: three in Nagoya 
under the NEW umbrella, one in Shizuoka, and one in Kyoto. The plants in Shizuoka and Kyoto were built specifically to meet the demands of the Army and the Navy, which were each scrambling for as big a share of engines as they could get; when they became operational the Munitions Ministry had already been established, and the engines from these two plants were divided between the two forces proportionately. The American bombing raids over Japan began shortly after the two plants went into full operation, and not long afterwards the war came to an end, so only a small number of engines were made at these two plants.

It is important to note that structural development in the little over five years of NEW's independent existence did not involve mere expansion; rather, it took the form of an organic unification of the whole organization. Basically it moved in the direction of hiving off into independent entities any shops that had become devoted to specialized operations. In response to the increase in the number of engine manufacturing plants, the manufacturing (or processing) of certain parts that were in common demand in all the plants was carried out centrally in a separate factory; this was done with a view to exercising production management that integrated the whole engine manufacturing division, as well as with a view to improving production efficiency. In addition, by devolution of authority to each of the plants, top management aimed at delegating responsibilities and authority to managers and supervisors and thus at raising morale in the workplace.

This kind of structure building was not to be found in, for example, the airframe division of Mitsubishi. Remarkable advances were made there, indeed, in aviation technology and production technology, and new departments and sections were created. But that division had adopted as its outer framework a complete separation between its Army and Navy customers, and it added on new aircraft body workplaces in line with this separation. Once it ended up with a system that engaged in developing and producing different aircraft bodies for different lines in the Army and the Navy, it would most likely have been too difficult to find items that were common to the two end users and to reorganize the entire structure. In the case of Nakajima, it did have factories (including those of affliliated companies) engage exclusively in making engine parts, but it was deeply involved, right from its very structural formation, in doing work for the military. Thus, when you think of all 
the companies engaged in aircraft manufacture during the war, when it comes to the new formation of a network of specialized factories that was unique to a specific individual enterprise, Fukao's system building was an outstanding achievement. Despite this achievement, however, his production system was unable to fully manifest its advantages, as the wartime economy was beset by more and more desperate circumstances, and then the war came to a sudden end.

\section{PRODUCTION PEAKS AND LIMITATIONS}

Figure 3 presents an indexation of business performance in Mitsubishi's aero-engine division. The abrupt increase in productivity in 1944 despite

Figure 3. Business Results (Indexes) of Mitsubishi Heavy Industries' Aero-engine Division during the War

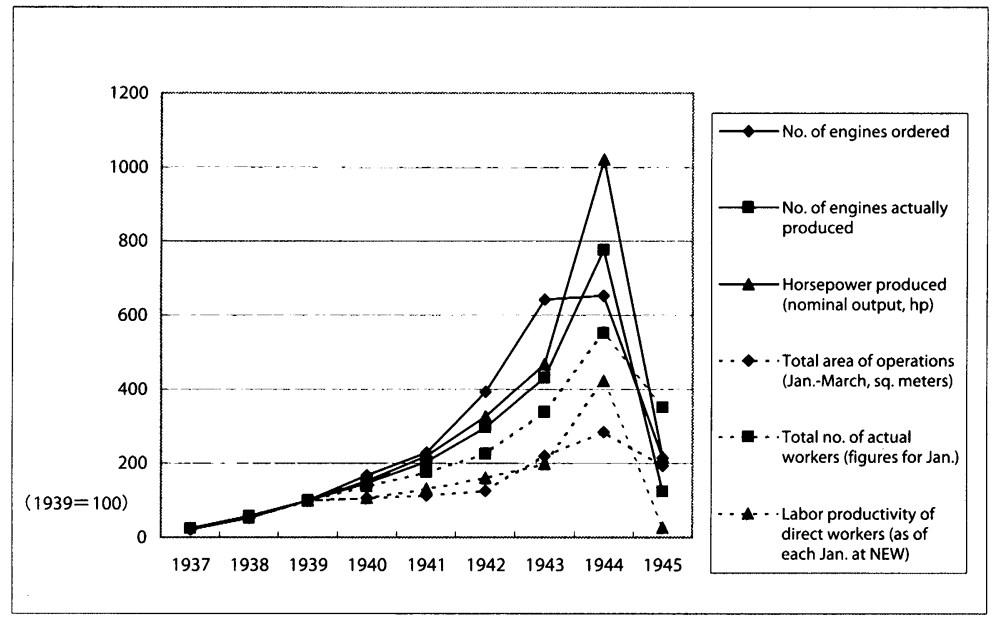

Note: The figures for the total area of operations in 1945 is for the period April-June, but for the total number of actual workers is for the month of January.

Source: Mitsubishi Köküki ryaku shi [Abridged history of Mitsubishi Aircraft] (Mitsubishi Heavy Industries Co., Ltd., company history archives), pp. 23642-44, 23680-81, and 23704-15. 
the nationwide shortage of materials and skilled labor is in large part due to preferential treatment given to the aircraft industry, then to the structural soundness of the company and its improved production technology.

Noteworthy among the factors of a production technology nature were such things as the introduction of conveyor lines and the development of the transfer machine. Such pieces of equipment for large-scale production were first introduced into the machining processes, where many identical pieces are handled, but when one considers them in terms of when they were in actual use, one has to say that the passing on of their experience after the war was of more significance than the role they played in increasing production during the war. The move toward flow operation in the assembly processes, an area where Japan lagged far behind the United States, also made steady progress, being oriented to a certain extent in the direction of the tact system. In addition, in those factories specializing in making parts that were suitable for speculative production because they were of standardized specifications, it seems the flow operational method was functioning quite efficiently. On the other hand, in the dying months of the war various desperate attempts were being made to increase production so as to maintain the ability to wage war: wartime machine tools that were a desperate retrogression of the concept of using a lot of specialized machines; ${ }^{9}$ the adoption of inspection methods acceptable only in a desperate wartime situation; and the development of wartime engines.

Production peaked in August and September of 1944. This means that, three to four months before air raids began taking their toll on factories, Japan's wartime production already showed clear limitations. The shortage of materials, particularly the shortage of rare metals, had led to deterioration of the materials used in production, and these inferior materials caused great problems. If a company tried to maintain the quality of its products with inferior materials, the attempts would have a

9. "Wartime machine tools" signify single-purpose machines that were drastically simplified so as to reduce the amounts of materials, labor, time, and electric power needed for manufacturing, with a view to making it possible for even inexperienced workers to process items (using only that one machine) that had been processed in the past by using a combination of the old multipurpose machines and specialized tools or jigs. 
significant influence on its production processes. What was at stake was the fate of any high-tech product like an airplane engine.

\section{ConClusion}

During the war Mitsubishi's aircraft engine production rested on the integration of several factories and structural functions. It began with product development, followed by the development and manufacture of special-purpose machines and jigs and tools, the internal manufacturing of material parts and special parts, the nurturing of technical skills and the purchasing of goods from outside sources (two matters that could not be taken up within the confines of this paper), the balanced provision of parts and attachments, attempts at organically integrating and efficiently running not just the machining and assembly processes but all the processes, and a heightened realization of the importance of management of the whole process-the "structural aspect" of production technology. For all of this to happen, strong leadership was required, and this was what Junji Fukao provided. Here was one private enterprise making an attempt to produce on a large scale an aircraft engine-a product requiring high technology, one in which maintaining quality is a high priority, and one that is unavoidably accompanied by design changes - at a time when the machine manufacturing industry as a whole was at a low level, and he adopted this method as the quickest means of achieving that company's production targets. The method met defeat in the end and the basic reason was the backward conditions of Japan's machine manufacturing industry itself; despite the setback, the method laid the groundwork for production technology in the next generation.

For indeed, the experiences trialed for a short time during the war would, after the war, over a long period of time, be revived once again, reviewed, smoothed out, and then go on to permeate the country's workplaces, where they keep on growing and evolving.

* This paper is a summary of a portion of the author's book published by University of Tokyo Press in 2001, entitled Senjiki köküki kōgyō to seisan gijutsu keisei: Mitsubishi kōkū enjin to Fukao Junji [Capacity Building in Production Technology for Manufactur- 
ing Aircraft Engines during Wartime: The Cases of J. Fukao and Mitsubishi Heavy Industries, Ltd.]. Footnotes to indicate the contents of personal interviews and the places where I have relied on Fukao's personal documents have been omitted; such details can be found in the original book. 